\title{
MAKNA JIHAD DALAM PERSPEKTIF PENDIDIKAN ISLAM
}

\author{
Yumni Al-Hilal \\ (yumni.alhila199@gmail.com) \\ Dosen Sekolah Tinggi Ilmu Tarbiyah (STIT) Islamic Village Tangerang
}

\begin{abstract}
Abstrak: Adakah Suatu hal yang telah diketahui dan disepakati bersama bahwa agama Islam adalah merupakan agama motivasi, dimaa setiap muslim diwajibkan untuk menuntut ilmu. Kata Tarbiyah yang berarti pendidikan mengajak kita kepada usaha yang keras dan sungguh-sungguh dalam rangka perbaikan mengubah situasi yang lebih baik dan sempurna baik terhadap pribadi maupun masyarakat. Tulisan ini dengan bahan-bahan yang terbatas akan menyoroti secara khusus, beberapa persoalan tentang makna jihad dan problematika dalam kerangka pendidikan Islam. Urgensi pembahasan ini lebih terasa lagi setelah disadari bangkitnya kesadaran beragama kaum muslimin dimana-mana. Yang mana kemudian mendorong mereka melaksanakan perintah agama dengan sebaikbaiknya termasuk didalamnya masalah pelaksanaan jihad dan pendidikan Islam yang menjadi pokok bahasan makalah ini.
\end{abstract}

Kata Kunci: Problematika Makna Jihad, Kerangka Pendidikan, Ajaran Islam

\section{A. Makna Jihad}

Jihad terambil dari kata al-juhdu artinya kekuatan dan kemampuan. Ada yang berpendapat kata al juhdu bisa dibaca al jahdu yang berarti kesulitan dan kesukaran

Jadi al-juhdu atau al-jahdu Berarti pengerahan kekuatandan kemampuan untuk sesuatu yang lain dengan segala kesulitan dan kesukarannya. ${ }^{263}$

Kata jihad merupakan masdar dari jahada seperti dalam kalimat, "Jahada fulanul aduwwuhu yang artinya, Fulan melawan musuhnya dengan mengerahkan usaha, atau masing-masing mengeluarkan usaha dan kekuatan untuk menolak lawan-lawannya. ${ }^{264}$

Dari arti-arti yang ditunjukan seperti tersebuat di atas, jihad berarti aksi diantara dua belah pihak, dengan mengerahkan usaha. Usaha yang keras, dan sungguh-sungguh untuk memperoleh kemenangan. Pengertian etimologi yang tersebut di atas mencakup pula didalamnya makna al-Qital (perang bersenjata)

\footnotetext{
${ }^{263}$ Salman bin Fahd Al-Audah, oleh pengarang kitab "min wasa'il dafil ghurbah, keterangan kata berasal dari kata berdasarkan sumber pengambilannya dari al qomus al muhith 1/296, dan al mushabbil manir, 3/112.

${ }^{264}$ Ibid.
} 
ISTIGHNA, Vol. 1, No 2, Juli 2018 P-ISSN 1979-2824

Homepage: http://e-journal.stit-islamic-village.ac.id/index.php/istighna

Yumni Al-Hilal

Makna Jihad dalam Perspektif Pendidikan Islam

puncak pengerahan tenaga. Mengajak (dengan lisan) dalam mengemukakan bantahan dengan kata-kata dan argumentasi terhadap orang-orang kafir dan para penantangnya. $^{265}$

Dari pengertian etimologi yang menjadi dasar pijakan seperti yang telah diuraikan diatas, membawa pengertian tentang jihad yang berarti ialah usaha keras dalam mengerahkan seluruh kemampuan dan kekuatan baik dalam perang, berbicara dengan lisan atau bentuk usaha apapun yang dilakukan dalam rangka menggerakan dan memuliakan kalimah Allaah dan agama-Nya.

Dari kajian sepihak tentang makna jihad baik dari segi bahasa (etimologi) maupun terminologinya, membawa kita kepada pemahaman dan semakin menyadari akan adanya hukum alam atau sunatullah tentang permusuhan dan dominasi sebagian manusia terhadap sebagian yang lain, karena adanya perbedaan diantara mereka, dan segala hal yang diakibatkan oleh perbedaan, apakah itu berupa permusuhan maupun peperangan yang berlangsung antara kebaikan dan keburukan, hak dan batil, Islam dan kufur, sunah dan bid'ah, jalan lurus dan menyimpang dan bentuk-bentuk pertentangan lainnya diantara manusia, diakibatkan diantara mereka.

Pertentangan tersebut akan terus berlangsung dan berkecamuk dibelahan dunia ini sebagai ketetapan sunnah Allaah dan sebagai orang-orang yang memperjuangkan dan menyerahkan kepada kebaikan, kebenaran, jalan-jalan yang lurus, sunnah Nabi, dan nilai-nilai keislaman lainnya, akan selalu menemui dan menerima kesukaran, kesulitan, dan cobaan-cobaan lainnya yang tak pernah berhenti, demikian pula orang-orang yang sabar memegang teguh agamanya, dan terhadap orang yang tetap meniti kepada jalan yang lurus.

Capaian pengertian inilah yang dimaksud dalam kajian ini yakni cakupan maknanya (baca jihad) yang luas dan komprehensif seperti yang dimaksud oleh al-Qur'an dan sunnah.

\section{B. Macam-Macam Jihad}

${ }^{265}$ Syaikh Abdurrahman Abdul Khaliq, Methode dan Strategi Dakwah Islam, Penerjemah Marsuni Sasaky \& Mustahab Hasbullah, Jakarta, Pustaka Al-Kautsar, cet- 1, hal. 21 
ISTIGHNA, Vol. 1, No 2, Juli 2018 P-ISSN 1979-2824

Homepage: http://e-journal.stit-islamic-village.ac.id/index.php/istighna

Yumni Al-Hilal

Makna Jihad dalam Perspektif Pendidikan Islam

Jihad dapat dibagi menurut alat yang dipergunakan seperti yang telah dianjurkan dan diperintahkan oleh Nabi SAW dari hadits yang dibawa Anas ra:

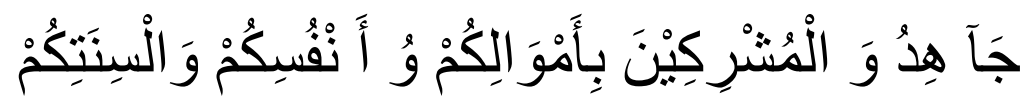

"Perangilah orang-orang mustrik dengan harta, diri dan lidahmu",266

Menurut hukum jihad terbagi jihad wajib dan jihad sunnah. Sedang menurut objek dan sasarannya jihad dapat dibagi menjadi jihad melawan nafsu, jihad melawan syaiton, jihad melawan orang-orang kafir, musyrik, munafik dan jihad melawan orang-orang fasik dan zalim. ${ }^{267}$

Dari semua pembagian dan macam jihad seperti yang disebutkan diatas, menurut pertimbangan dan kriterianya masing-masing dan memperhatikan definisi dan pengertian makna jihad yang telah dijelaskan di muka, maka jihad itu bisa dibagi menjadi tiga macam bentuk, seperti dirumuskan oleh Syekh Abdur Rahman Abdul Khaliq ${ }^{268}$ :

1. Bentuk informasi (pers) yang semata-mata memberi informasi di dalam al-Qur'an seringkali menggunakan ungkapan tabsyir dan nadzarah (memberi kabar gembira dan peringatan). Demikian pula dalam memberi bantahan dan adu argumentasi yang bertujuan mematahkan gambarangambaran keliru dan kebohongan-kebohongan yang dilancarkan pihak musuh. Kesemuanya itu dapat digolongkan dakwa Qauliyah.

2. Berbentuk pendidikan dan bimbingan yang merupakan bagian terbesar dari jihad, termasuk di dalamnya berbagai macam metode dakwah yang mencakup perkataan dan lainnya.

3. Memerangi kaum kufur, inilah bentuk puncaknya jihad dijalan Allaah, dan berperang itu memiliki aturan-aturan dan hukumnya sendiri yang mana hal ini sering diabaikan.

Bilamana kita mencermati pembagian dan klasifikasi jihad yang ditetapkan oelh Syekh Abdur Rahman Abdul Khalik di atas, dari masing-masing ketiga

${ }^{266}$ Hadits ini diriwayatkan Abu Daud, Katabul Jihad, Hadits Nomor 2504, 3/22. Juga oleh An Nasaiy, Ahmad, Al Hakim, Ibnu Hubban, Al Baihaqi, Semua darijalan Hamad, dari Humaid, dari Anas.

${ }^{267}$ Ibid, hal. 15

${ }^{268}$ Op.cit, hal, 22 
ISTIGHNA, Vol. 1, No 2, Juli 2018 P-ISSN 1979-2824

Homepage: http://e-journal.stit-islamic-village.ac.id/index.php/istighna

Yumni Al-Hilal

Makna Jihad dalam Perspektif Pendidikan Islam

macam bentuk di atas, kita dapati fenomena bentuk-bentuk jihad tersebut dan kaitannya dengan gerakan pendidikan telah berlangsung sejak lama di negeri kita dengan segala dinamika dan pasang surutnya yang mewarnai kegiatan pendidikan Islam dan pembaharuan didalamnya. Komponen-komponen masyarakat muslimin menjalankan fungsinya masing-masing sesuai dengan kemampuan yang dimilikinya.

Hampir semua organisasi masyarakat Islam yang ada di tanah air telah memiliki dan menerbitkan media masanya masing-masing, yang kesemuanya media massa itu mempunyai misi orientasi yang sama yakni gerakan pendidikan dalam bentuknya yang pertama yaitu bentuk informasi, terutama ditujukan kepada komunitas mereka dan warganya yang dibawa dan masing-masing organisasi masyarakat Islam harus diakui memiliki perbedaan-perbedaan dan ciri khasnya masing-masing, seperti organisasi NU, Muhammadiyah, Persis dan lain-lainnya. Yang masing-masing merupakan organisasi masyarakat keagamaan yang cukup besar dan berpengaruh di Indonesia.

Demikian pula, dalam dunia pendidikan agama dan dimbingan-bimbingan dakwah, bila kita amati, sebagian besar dari jihaddalam bentuknya yang kedua, yakni bentuk pendidikan dan bimbingan, peran dan fungsi tersebut banyak dilakukan dan dijalankan oleh dua organisasi Islam terbesar di Indonesia yakni NU \& Muhammaddiyah yang relative berjalan dengan kekurangan-kekurangan dan kelebihan-kelebihan diantara keduanya, tetapi yang jelas dan harus diakui sumbangan dan kontribusi mereka dalam memajukan dan mengembangkan bidang pendidikan di tanah air adalah sangat besar dan berarti.

Berkaitan dengan jihad dalam bentuknya yang ketiga yakni memerangi kaum kufur, dan inilah bentuk puncaknya jihad di jalan Allaah, kata "Jihad fi sabilillah" sangat sering dipakai, karena akan dengan mudah membangkitkan emosi keagamaan seseorang, apalagi dihadapkan dengan sentiment agama lain.

Seruan atau term-term "Jihad fi sabilillah" juga sering menimbulkan persoalan, karena seringkali disalahgunakan dan dimanipulasi oleh para tokoh politik dan tokoh muslim untuk kepentingannya sendiri atau tujuan-tujuan politik terntentu yang melatar belakangi dan menutupi kepentingan politik pribadi 
ISTIGHNA, Vol. 1, No 2, Juli 2018 P-ISSN 1979-2824

Homepage: http://e-journal.stit-islamic-village.ac.id/index.php/istighna

Yumni Al-Hilal

Makna Jihad dalam Perspektif Pendidikan Islam

maupun kelompoknya dengan mengusung seruan "Jihad fi sabilillah" mengatasnamakan agama demi mencapai tujuan dan keuntungan politik dan upaya-upaya itu seringkali berhasil, dan sering dilakukan oleh para politisi muslim dan pemimpin politik diberbagai penjuru dunia Islam.

Berperang dalam ajaran Islam tentu memiliki aturan-aturan dan hukumnya sendiri, yang mana hal itu sering diabaikan, karena memang sedikit orang yang mengetahui dan menyadari cakupan maknanya yang luas dan komprehensif seperti dimaksud oleh al-Qur'an dan as-Sunnah.

Fenomena atau realitas yang baru disebut di atas akan kurangnya pemahaman makna jihad, terutama makna "jihad fi sabilillah" pada masyarakat muslim awam, karena persoalan seringkali dengan mudahnya mengidentifikasi makna "jihad fi sabilillah" dengan berperang. Disinilah timbul persoalan dan perselisihan pendapat tentang makna jihad. Sebagian mereka berpendapat bahwa Jihad Fi Sabilillah hanya satu makna saja yakni berperang. Penda[at ini biasanya diwakili oleh kalangan kaum muslimin radikal, yang oleh bangsa barat biasa disebut golongan muslim fundamentalis. Dan sebagian lagi merekA yang lebih moderat memaknai Jihad fi Sabilillah bukan hanya dengan berperang semata-mata tetapi terkandung dimensi-dimensi lain, tergantung kepada situasi dan kondisi yang menyertainya. Maka sebetulnya banyak sekali kesempatan atau kegiatan yang dilakukan bisa dikategorikan jihad bila dikaitkan dengan kerangka pendidikan islam.

Dari perselisihan pendapat dan pandangan tentang makna jihad dan sedikitnya masyarakat muslim kebanyakan yang mengetahui dan menyadarai maknanya seperti yang telah diuraikan, tentu menimbulkan problematika atau makna jihad itu sendiri terutama bila dikaitkan dalam kerangka dakwah dan pendidikan Islam, karena seringkali terjadi akhir-akhir ini kelompok-kelompok Islam tertentu mengklaim diri mereka sebagai gerakan dakwah dan dengan berlindung atas nama jihad dalam rangka amar ma'ruf nahi munkar, mereka melakukan anarkisme pelanggaran hukum dan melakukan perusakan-perusakan atas hak milik orang lain dan menimbulkan perusakan-perusakan dan ancamanancaman bagi masyarakat, dan jelas hal itu menimbulkan akibat dampak negative 
ISTIGHNA, Vol. 1, No 2, Juli 2018 P-ISSN 1979-2824

Homepage: http://e-journal.stit-islamic-village.ac.id/index.php/istighna

Yumni Al-Hilal

Makna Jihad dalam Perspektif Pendidikan Islam

bagi citra Islam dan kemuliaan ajarannya. Mereka menampilkan Islam dengan wajah yang keras, kasar dan brutal sehingga menimnulkan rasa was-was, kegelisahan dan rasa tak tentram pada masyarakat lain, karena kegiatan dan aktifitas yang dilakukan mereka menamakan sebagai gerakan dakwah dan tentu sudah jelas bagi kita bahwasanya apa yang mereka lakukan telah bertolak belakang dari tujuan yang seharusnya, yakni menimbulkan ketertarikan, kesan yang baik, lemah lembut, dan penuh kedamaian sesuai dengan tujuan agama ini diturunkan yaitu sebagai rahmatan lil'alamin yaitu rahmat bagi alam semesta.I

\section{Kontrofensi Makna Jihad dalam Kerangka Pendidikan dan Ajaran Islam}

Dampak yang ditimbulkan oleh adanya dan masih berlangsungnya pemahaman yang salah atas penafsiran makna jihad, dan kecenderungan mereka memonopoli bahwasanya hanya penafsiran merekalah yang benar, sehingga mereka berhak melakukan kekerasan dan pemaksaan kehendak atas nama jihad atau seruan amar ma'ruf nahi munkar. Keyakinan semacam ini diantara dampaknya adalah menafsirkan jalan terpaksa (darurat) dalam hukum syara' dan memandang sama antara yang tidak tahu dalam hal pembebanana (taklif) hukum syara' dan antara orang-orang yang berusaha menta'wil dan yang membangkang, juga mereka secara tidak sadar telah menafsirkan mashalih syar'iyah (kemasalahatan-kemaslahatan hukum syara') dan perlakuan syariat Islam tanpa hikmah dan tanpa menggunakan akal sehingga gerakan-gerakan mereka berubah menjadi fitnah dalam agama.

Seperti yang telah dijelaskan sebelumnya di muka, akan pengertian jihad secara bahasa memang tercakup di dalam makna al-Qital (perang bersenjata) tetapi bukan hanya itu maknanya, karena masuk pula di dalamnya berdakwah dengan lisan dan melakukan bantahan terhadap orang-orang kafir dengan kemampuan yang dimiliki masing-masing dan tuntutan zamannya. Firman Allah:

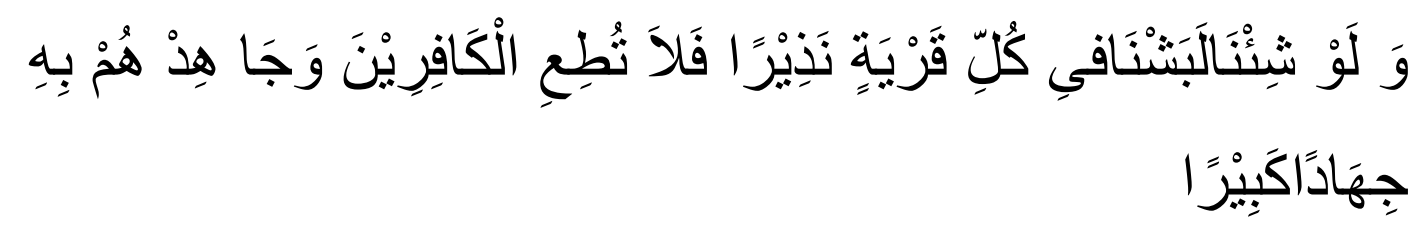

Artinya: 
ISTIGHNA, Vol. 1, No 2, Juli 2018 P-ISSN 1979-2824

Homepage: http://e-journal.stit-islamic-village.ac.id/index.php/istighna

Yumni Al-Hilal

Makna Jihad dalam Perspektif Pendidikan Islam

"Dan andaikata kami menghendaki, benar-benar kami utus pada tiap-tiap negeri orang yang memberi peringatan (Rasul). Maka janganlah kamu mengikuti orang-orang kafir dan berjihadlah terhadap mereka dengannya (al-Qur'an) dengan jihad yang besar" (Q.S Al-Furqan: 51-52)

Dhamir (kata ganti) yang terdapat pada (bihi) dikembalikan kepada kita Allaah Swt.

Berdasarkan pada ayat diatas, dapat ditarik kesimpulan bahwa berdakwah dengan kata-kata walaupun nanti bisa bermacam-macam, apakah ia ceramah, diskusi, atau seminar, maupun forum-forum ilmiah keagaman lainnya asal sudah mencakup tiga unsur dakwah yakni da'I mad'u, dan dakwah maka sudah termasuk sebagian dari jihad fi sabilillah (jihad di jalan Allah).

Hal ini tentu saja tidak dikhusukan terhadap orang-orang kafir saja, menasihati seseorangpun (muslim) termasuk juga jihad ${ }^{269}$, seperti yang disebutkan oleh Rasulullah SAW di dalam haditsnya:

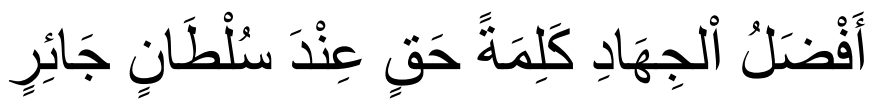

Artinya:

"Jihad yang paling utama adalah perkataan yang benar dihadapan penguasa yang zalim"

Tidak diragukan bahwa yang dimaksudkan oleh hadits di atas adalah seseorang yang zalim, maka menyampaikan dakwah dan menasehatinya adalah merupakan salah satu jihad yang paling utama (afdal) disisi Allah.

Selama ini, pendidikan dan pesan ajaran Islam datang membawa rahmat untuk menekankan seluruh alam dan tentunya lebih-lebih lagi untuk pemeluknya, tetapi sangat disayangkan kerahmatan tersebut tidak dirasakan menyentuh segisegi kehidupan nyata kaum muslimin, hal ini disebabkan antara lain karena yang menyentuh mereka dari ajaran agama selama ini, lebih banyak hanya pada segi ibadah ritual, sedangkan segi-segi lainnya untuk mengatasi kebutuhan dan kepentingan anggotanya, lainnya untuk mengatasi kebutuhan dan kepentingan anggotanya, khususnya dalam bidang ekonomi, pendidikan dan kesehatan

${ }^{269}$ Syaikh Abdurrahman Abdul Khaliq, Loc.cit, hal, 21-22 
ISTIGHNA, Vol. 1, No 2, Juli 2018 P-ISSN 1979-2824

Homepage: http://e-journal.stit-islamic-village.ac.id/index.php/istighna

Yumni Al-Hilal

Makna Jihad dalam Perspektif Pendidikan Islam

masyarakat masih kurang mendapat perhatian. Oleh sebab itu jihad dalam kerangka gerakan pendidikan Islam harus ditingkatkan dan mengambil peranan yang lebih besar.

\section{Kesimpulan}

Disini dikemukakan beberapa butir masalah berkaitan dengan kelompokkelompok dan sebab-sebab perbedaan pandangan diantara kaum muslimin dalam kehidupan keagamaan khususnya dalam penafsiran makna jihad.

(1) Tidak dapat disangkal bahwa perbedaan pendapat dalam segala aspek kehidupan manusia merupakan satu fenomena yang telah lahir bersamaan dengan lahirnya masyarakat dan hanya berakhir dengan berakhirnya kehidupan masyarakat. Umat Islam tidak terkecuali akan terkena fenomena tersebut sejak zaman Nabi SAW, walaupun tentunya perbedaan-perbedaan ini tidak meruncing karena kehadiran Nabi SAW ditengah-tengah mereka ${ }^{270}$. Dalam perkembangan lebih lanjut, perbedaan-perbedaan tersebut melahirkan aliran-aliran dalam Islam bahkan kemudian menjadikan umat Islam tersebut terbagi menjadi berkelompok-kelompok.

(2) Salah satu penyebab timbulnya perbedaan tersebut adalah dikarenakan redaksi ayat-ayat al-Qur'an dan hadits-hadits Nabi SAW tidak seorangpun dapat memastikan maksud sebenarnya dari suatu redaksi dari ucapan, kecuali pemiliknya sendiri sehingga pengertian yang dipahami oleh pembela atau pendengar dapat saja bersifat relative. Tetapi walaupun demikian, hal itu tidak berarti tidak ada tolak ukur untuk memiliki suatu pendapat, atau kedekatannya kepada kebenaran. ${ }^{271}$

(3) Salah satu dari kelima pokok ajaran adalah pemeliharaan terhadap agama itu sendiri, yang antara lain menuntut peningkatan pemahaman umat terhadap ajaran agamanya, serta usaha membentengi mereka dari segala bentuk dari kemurniannya. Benar bahwa manusia diberi kebebasan untuk "memilah" agama itu, sehingga menganut apa yang dianggap sesuai dan

${ }^{270}$ Lihat M. Quraish Shihab, Memberikan Al-Qur'an, Bandung: Mizan, 1995, cet, IX; h.396

${ }^{271}$ Ibid 
ISTIGHNA, Vol. 1, No 2, Juli 2018 P-ISSN 1979-2824

Homepage: http://e-journal.stit-islamic-village.ac.id/index.php/istighna

Yumni Al-Hilal Makna Jihad dalam Perspektif Pendidikan Islam

menolak yang dianggap tidak sesuai. Disini perlu digaris bawahi, bahwa ada sekian banyak masalah-masalah keagamaan yang kait berkait dengan berbagai disiplin ilmu. Sehingga, ketika memberikan keputusan agama, para ahli dalam berbagai disiplin dan bidang terkait seharusnya berperan serta bersama agamawan dalam memecahkannya. ${ }^{272}$

Butir-butir di atas mengantarkan kita untuk berkesimpulan bahwa kelompok-kelompok seperti digambarkan di atas tidak serta merta dijatuhi hukuman vonis "sesat atau menyesatkan" sebagaimana yang kadang terjadi dewasa ini. Kita tidak berhak memutarbalikan fakta, tetapi harus menghadapi mereka dengan argumentasi-argumentasi ilmiah yang kokoh serta dengan dada yang lapang.

Dari uraian diatas, kiranya disimpulakn bahwa jihad dalam bidan pendidikan adalah dua kegiatan atau bisa jadi satu paket yang tidak bisa dipisahkan, maka harus didukung oleh uraian-uraian ilmiah dan logis serta menyentuh hati dan menyejukan.

\section{Daftar Pustaka}

Abdul Khaliq, Abdurrahman, Syaikh, Methode dan Strategi Dakwah Islam, Penerjemah, Marsumi Sasaky \& Mustahab Hasbullah, Jakarta: Pustaka alKautsar, 1996, cet. 1

Al-Audah, Salman bin Fahd, Jihad Sarana Menghilangkan Ghubah Islam Penerjemah, Kathur Suhardi, 1996, cet. 1

Shibah, M. Quraish, Dr. M. A. Membumikan Al-Qur'an, Bandung: Mizan, 1995, cet-IX

${ }^{272}$ Ibid, hal. 397 